\title{
Pharmacological profile of inhibition of the chloride channels activated by extracellular acid in cultured rat Sertoli cells
}

\author{
Céline Auzanneau, Caroline Norez, Sabrina Nö̈L, Chantal Jougla, \\ Frédéric BECQ, Clarisse VANDEBROUCK*
}

Institut de Physiologie et de Biologie Cellulaires CNRS UMR 6187,Université de Poitiers, 86022 Poitiers, France

(Received 4 November 2005; accepted 24 February 2006)

\begin{abstract}
Sertoli cells from mammalian testis are key cells involved in the development and maintenance of stem cell spermatogonia as well as in the secretion of $\mathrm{Cl}^{-}$and $\mathrm{K}^{+}$-rich fluid into the lumen of seminiferous tubules. The pharmacology and contribution of $\mathrm{Cl}^{-}$channels to the physiology of Sertoli cells were investigated using whole-cell patch clamp and iodide efflux experiments applied to cultured rat Sertoli cells. We characterized an outwardly rectifying $\mathrm{Cl}^{-}$current stimulated by various acid species including the physiologically relevant lactic acid. Using the iodide efflux technique, the pharmacological properties of this $\mathrm{Cl}^{-}$current, noted $\mathrm{ICl}_{\text {acid }}$, revealed $\mathrm{Ca}^{2+}$ independent inhibition by DIDS $\left(\mathrm{IC}_{50}=27 \mu \mathrm{M}\right)$, glibenclamide $\left(\mathrm{IC}_{50}=31 \mu \mathrm{M}\right)$ and DPC $\left(\mathrm{IC}_{50}=\right.$ $86 \mu \mathrm{M})$. ICl $\mathrm{ICid}_{\text {cid }}$ was neither affected by calix[4]arene nor by 9 -AC. The order of potency for inhibition of $\mathrm{ICl}_{\text {acid }}$ is DIDS $\approx$ glibenclamide $>$ DPC $>>$ calix[4]arene, 9-AC. For comparison, the inhibitory profile of the swelling- and ATP-activated $\mathrm{Cl}^{-}$currents in Sertoli cells is DPC = DIDS $>$ glibenclamide $=9-\mathrm{AC}$ for $\mathrm{ICl}_{\text {swell }}$ and $\mathrm{DPC}=9-\mathrm{AC}=\mathrm{DIDS}>>$ glibenclamide for $\mathrm{ICl}_{\mathrm{ATP}}$. This description provides new insights into the physiology and pharmacology of the endogenous $\mathrm{Cl}^{-}$ channels expressed and potentially involved in fluid secretion in Sertoli cells.
\end{abstract}

$\mathrm{Cl}^{-}$channels / pharmacology / proton-activation / ATP / cell volume / glibenclamide

\section{INTRODUCTION}

In the mammalian testis, the somatic Sertoli cells, discovered by the Italian physiologist and histologist Enrico Sertoli in 1865 , play a key role in the initiation and maintenance of spermatogenesis, in the development of a functional testis, and hence in the expression of the male phenotype [1-3]. The structure of Sertoli cells and the specialized junctions between

\footnotetext{
* Corresponding author:

clarisse.vandebrouck@univ-poitiers.fr
}

them and the neighboring germ cells create an immunologically protected space [4], a barrier to protect developing germ cells against harmful agents and a sophisticated microenvironment providing all the nutrients, a variety of hormones [5] and growth factors required for the full development of germ cells [1-3]. In the rat, Sertoli cells proliferate during the fetal and early neonatal periods before assuming a terminally differentiated state $[6,7]$.

Sertoli cells are also responsible for the secretion of a chloride and potassium- 
rich fluid in the lumen of seminiferous tubules [8]. Cytosolic calcium $\left[\mathrm{Ca}^{2+}\right]_{\mathrm{i}}$ also plays an important role in the biochemistry and physiology of immature Sertoli cells $[9,10]$. Cytosolic calcium signaling is involved in the regulation of intracellular $\mathrm{pH}$, which appears to play an important role in secretory processes in response to hormones $[9,11]$. In addition, an acidic microenvironment is crucial for male fertility since sperm cannot fertilize an egg without proper acidification of the acrosome [12]. Sertoli cells secrete lactate in the presence of glucose [13]. Because germ cells degenerate in the absence of lactate [14], isolated spermatocytes and round spermatids may utilize lactate secreted by Sertoli cells, as the main source of energy [13].

To fulfil these important physiological functions, Sertoli cells must have developed complex transport systems of ions and monocarboxylate acids. Indeed Sertoli cells express a variety of membrane transporters such as $\mathrm{Na}^{+} / \mathrm{H}^{+}$ and $\mathrm{Na}^{+}$-dependent $\mathrm{Cl}^{-} / \mathrm{HCO}_{3}^{-}$exchangers and $\mathrm{Na}^{+} / \mathrm{HCO}_{3}^{-}$co-transporters [9]. Electrophysiological and molecular analysis revealed the expression of several types of ionic channels, among them voltage-dependent $\mathrm{Ca}^{2+}$ channels [15], $\mathrm{Ca}^{2+}$-dependent $\mathrm{Cl}^{-}$channels [16], CFTR $\mathrm{Cl}^{-}$channels [17] and voltage-dependent $\mathrm{Cl}^{-}$channels including $\mathrm{rClC}-2, \mathrm{rClC}-3$, rClC-6, rClC-7 [18]. In addition, we recently identified a voltage-dependent $\mathrm{Cl}^{-}$ current activated by extracellular acidic $\mathrm{pH}$ (hereafter noted $\mathrm{ICl}_{\mathrm{acid}}$ ) in rat Sertoli cells [18]. This novel acid-activated $\mathrm{Cl}^{-}$ current may be of particular interest for the physiology of Sertoli cells considering the importance of endogenous production of lactate $[13,14]$.

We report here the pharmacology of an outwardly rectifying $\mathrm{Cl}^{-}$current activated by extracellular acid $\mathrm{pH}$ in rat Sertoli cells and compared some of its pharmacological properties to those of two other different endogenous $\mathrm{Cl}^{-}$channels activated by extracellular ATP $\left(\mathrm{ICl}_{\mathrm{ATP}}\right)$ or in response to osmotic swelling $\left(\mathrm{ICl}_{\text {swell }}\right)$. In particular, we found the sulfonylurea agent glibenclamide as a discriminator of $\mathrm{ICl}_{\text {acid }}$ compared to $\mathrm{ICl}_{\text {ATP }}$ or $\mathrm{ICl}_{\text {swell }}$ whereas $9-\mathrm{AC}$ is a good discriminator of $\mathrm{ICl}_{\mathrm{ATP}}$ compared to $\mathrm{ICl}_{\text {acid }}$ or $\mathrm{ICl}_{\text {swell }}$. Collectively this information will help to promote our understanding of the biophysical characteristics and physiological roles of the endogenous $\mathrm{Cl}^{-}$channels in the Sertoli cell, a cell at the blood-testis barrier.

\section{MATERIAL AND METHODS}

\subsection{Preparation of rat Sertoli cells}

Experiments were performed on cultured Sertoli cells isolated in sterile conditions from 13- to 15-day-old Wistar rats. Animals, raised at constant temperature $\left(20{ }^{\circ} \mathrm{C}\right)$ under a $12 \mathrm{~L}: 12 \mathrm{D}$ light cycle, were killed in agreement with a procedure approved by the local animal ethics committee and the testes were removed aseptically. Then, the parenchyma of 6-10 testes were submitted at $34{ }^{\circ} \mathrm{C}$ to two enzymatic treatments by collagenase and pancreatin. The interstitial tissue was separated from tubules by incubation and continuous shaking (90 cycles/min, $10 \mathrm{~min}$ ) in $25 \mathrm{~mL}$ medium A supplemented with $4.7 \mathrm{mg}$ collagenase (Worthington Biochemical Corporation; $390 \mathrm{u} \cdot \mathrm{mg}^{-1}$ ). Medium A was a $\mathrm{Ca}^{2+}$ - and $\mathrm{Mg}^{2+}$ - free modified Earle solution containing (in $\mathrm{mM}$ ) the following: $116.3 \mathrm{Na}^{+}, 5.4 \mathrm{~K}^{+}, 121.7 \mathrm{Cl}^{-}, 0.9$ $\mathrm{H}_{2} \mathrm{PO}_{4}^{-}$, and 5.5 glucose, supplemented with 53.5 mannitol and 20 Hepes and with streptomycin sulfate $\left(100 \mathrm{mg} \cdot \mathrm{mL}^{-1}\right)$ and penicillin $\mathrm{G}\left(100 \mathrm{IU} \cdot \mathrm{mL}^{-1}\right)$ (Sigma). The $\mathrm{pH}$ was adjusted to 7.4 and the osmolarity to $300 \mathrm{mOsmol}$ by mannitol. The medium was sterilized by filtration through a 0.22- $\mu \mathrm{m}$-pore filter (Millipore, Molsheim, France). Tubules were then allowed to sediment for $5 \mathrm{~min}$, and the supernatant was removed. Then they were resuspended 
in $10 \mathrm{~mL}$ of medium $\mathrm{A}$ and shaken by hand for $10 \mathrm{~s}$. The washing procedure was repeated four or five times. The tissue was minced with scissors and washed five times with $10 \mathrm{~mL}$ of medium $\mathrm{A}$, then allowed to sediment for $5 \mathrm{~min}$. The second dissociation was carried out to detach peritubular cells, comprising myoid cells and fibroblasts embedded in a collagen network, from the tubular wall. This was performed under continuous shaking (90 cycles/min, $5 \mathrm{~min}$ ) in $25 \mathrm{~mL}$ of medium A containing $12.5 \mathrm{mg}$ of pancreatin (grade VI; Sigma). The pancreatin solution was then discarded, and peritubular cells were separated from fragments of seminiferous tubules by gentle shaking in the presence of $10 \mathrm{~mL}$ of medium A (five times). Suspended fragments of free seminiferous tubules were discarded after centrifugation. Sedimented fragments were resuspended in $10 \mathrm{~mL}$ of medium A and passed about ten times through a syringe needle (17 gauge) at a slow rate. Cell suspension was adjusted to a volume of $10 \mathrm{~mL}$ with the following culture medium: DMEM/NUT mix F-12 (HAM) (Gibco BRL, UK) supplemented with insulin $\left(0.01 \mathrm{mg} \cdot \mathrm{mL}^{-1}\right.$; Sigma), BSA (1 mg. $\mathrm{mL}^{-1}$; Sigma), transferrin $(0.005 \mathrm{mg} / \mathrm{ml}$; Sigma), streptomycin sulfate $\left(100 \mathrm{mg} \cdot \mathrm{mL}^{-1}\right.$; Sigma) and penicillin G (100 IU.mL ${ }^{-1}$; Sigma). Final cell preparations were plated at low density in $35-\mathrm{mm}$ plastic dishes (Nunclon) for patchclamp or in 24 -well plates $\left(5 \times 10^{5}\right.$ cells $)$ for iodide efflux experiments. After two days, a hypotonic shock (20 mM TrisHCl solution) was applied to eliminate germ cells. Culture dishes were incubated at $34{ }^{\circ} \mathrm{C}$ a further $2-6$ days in a humidified $\mathrm{CO}_{2}$ incubator $\left(5 \% \mathrm{CO}_{2}: 95 \%\right.$ ambient air). From day 2 on, the medium was renewed at 2-day intervals.

\subsection{Electrophysiology}

Whole-cell currents were measured in the broken-patch, whole-cell config- uration of the patch clamp [19] using an RK300 patch clamp amplifier (Biologic, France). The holding potential was $-40 \mathrm{mV}$ in all whole-cell experiments. Current/voltage (I-V) relationships were built by clamping the membrane potential to $-40 \mathrm{mV}$ and by pulses from $-100 \mathrm{mV}$ to $+100 \mathrm{mV}$ in $20 \mathrm{mV}$ increments. Pipettes with resistance of 3-5 $\mathrm{M} \Omega$ were prepared by pulling borosilicate glass capillary tubes (GCL150-TF10, Clark Electromedical Inc., Reading, UK) using a two-step vertical puller (Narishige, Japan). They were connected to the head stage of the patch clamp amplifier through an Ag$\mathrm{AgCl}$ pellet. Seal resistances ranging from 3 to $15 \mathrm{G} \Omega$ were obtained. Pipette capacitance was electronically compensated for in a cell-attached mode. Membrane capacitance $(25.8 \pm 2.1 \mathrm{pF} ; n=13)$ and series resistances $(3.4 \pm 1.1 \mathrm{M} \Omega ; n=13)$ were measured in the whole-cell mode by fitting capacitance currents, obtained in response to a hyperpolarization of $6 \mathrm{mV}$, with a firstorder exponential, and by integrating the surface of the capacitance current. They were not compensated. Voltage-clamp signals, allowing the membrane potential to be held at different values, were applied and recorded with the resulting currents by means of a microcomputer equipped with an analog/digital-digital/analog conversion board (TM-40; Tekmar, Cincinnati, $\mathrm{OH})$. The results were analysed with the pCLAMP5.5 package software (pCLAMP, Axon Instruments). The external bath solution contained (in $\mathrm{mM}$ ) the following: $161 \mathrm{NaCl}, 5 \mathrm{CsCl}, 2 \mathrm{CaCl}_{2}$, $2 \mathrm{MgCl}_{2}$ and 10 HEPES-NaOH (pH 7.4, $370 \mathrm{mOsmol}$ ). The intrapipette solution contained (in $\mathrm{mM}$ ) the following: $1 \mathrm{NaCl}$, $39 \mathrm{CsCl}, 81$ CsGlutamate, $9.1 \mathrm{CaCl}_{2}$, $3 \mathrm{MgCl}_{2}, 10$ EGTA, 10 HEPES (pH 7.2, $300 \mathrm{mOsmol}$ ). The EGTA-calcium buffer was used to hold the intracellular free calcium concentration at $1 \mu \mathrm{M}$. The pipette solution was always hypotonic (with respect to the bath solution) to prevent cell 
swelling and activation of the volumesensitive chloride channels [18]. All experiments were conducted at room temperature $\left(20^{\circ} \mathrm{C}\right)$. The calculated chemical equilibrium potential for chloride $\left(\mathrm{E}_{\mathrm{Cl}-}\right)$ is $-25 \mathrm{mV}$ and for sodium $\left(\mathrm{E}_{\mathrm{Na}+}\right)$ is $+130 \mathrm{mV}$. The relative permeability of the channel to sodium and chloride $\left(\mathrm{P}_{\mathrm{Cl}}: \mathrm{P}_{\mathrm{Na}}\right)$ was estimated from the reversal potential of the current-voltage relationship using the classical GHK equation. Osmolarity was corrected with mannitol. For hypo-osmotic challenge, we used the external bath solution in which the osmolarity was modified to $200 \mathrm{mOsmol}$. Extracellular $\mathrm{pH}$ was adjusted with $\mathrm{HCl}$, lactic or aspartic acid as indicated in the text. The cells were stimulated with the appropriate compound at the concentration indicated in the text (dissolved in dimethyl sulfoxide $\mathrm{Me}_{2} \mathrm{SO}$; final concentration: $0.1 \%$ ). All current traces shown in the figures are single traces.

\subsection{Radiotracer efflux experiments}

Chloride channel activity was assayed by measuring the rate of iodide $\left({ }^{125} \mathrm{I}\right)$ efflux from a population of Sertoli cells. Cells were cultured in multiwell plates in order to perform parallel experiments and comparison analysis using a robot-based system (MultiProbe II ${ }^{\circledR}$, PerkinElmer Life Sciences, Courtabœuf, France) adapted to the iodide efflux method [20,21]. The cells were washed with an efflux buffer containing (in $\mathrm{mM}$ ) the following: $136.9 \mathrm{NaCl}$,

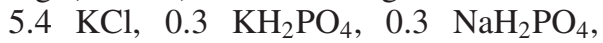
$4.2 \mathrm{NaHCO}_{3}, 2 \mathrm{CaCl}_{2}, 0.5 \mathrm{MgCl}_{2}, 0.4$ $\mathrm{MgSO}_{4}, 5.6$ glucose and 10 HEPES, $\mathrm{pH}$ 7.4. The cells were then incubated in an efflux buffer containing $1 \mu \mathrm{M} \mathrm{KI}$ and $1 \mu \mathrm{Ci}$ $\mathrm{Na}^{125} \mathrm{I} . \mathrm{mL}^{-1}$ (NEN, Boston, MA) during $1 \mathrm{~h}$ at $34{ }^{\circ} \mathrm{C}$ to permit the ${ }^{125} \mathrm{I}$ to reach equilibrium. The cells were then washed with an efflux medium to remove extracellular ${ }^{125} \mathrm{I}$. The loss of intracellular ${ }^{125} \mathrm{I}$ was determined by removing the medium with the efflux buffer every $1 \mathrm{~min}$ for up to $10 \mathrm{~min}$. The first three aliquots were used to establish a stable baseline in the efflux buffer alone. A medium containing the appropriate drug was used for the remaining aliquots. Residual radioactivity was extracted with $0.1 \mathrm{~N} \mathrm{NaOH} / \mathrm{SDS} 0.1 \%$, and determined using a gamma counter (Cobra $^{T M}$ II, PerkinElmer Life Sciences, Courtaboeuf, France). The fraction of initial intracellular ${ }^{125} \mathrm{I}$ lost during each time point was determined and time-dependent rates $\left(k, \min ^{-1}\right)$ of ${ }^{125} \mathrm{I}$ efflux were calculated from $k=\ln \left({ }^{125} \mathrm{I}_{t 1} /{ }^{125} \mathrm{I}_{t 2}\right) /\left(t_{1}-t_{2}\right)$ where ${ }^{125} \mathrm{I}_{t}$ is the intracellular ${ }^{125} \mathrm{I}$ at time $t$, and $t_{1}$ and $t_{2}$ are successive time points $[22,23]$. Curves were constructed by plotting $\mathrm{k}$ versus time. To compare different sets of data from separate experiments, the relative rates $(r)$ were calculated from $r=k_{\text {peak }}-k_{\text {basal }}\left(\min ^{-1}\right)$. In all experiments the peak rate $\left(k_{\text {peak }}\right)$ corresponds to the maximum value of the rate of efflux whereas the basal rate $\left(k_{\text {basal }}\right)$ represents the third point on the graphs except for Figure 4 where $k_{\text {basal }}$ is the fourth experimental point. All inhibitors were pre-incubated during $30 \mathrm{~min}$ before the beginning of the experiment.

\subsection{Chemicals}

Glibenclamide, DPC (diphenylamide2-carboxylic acid), 9-AC (Anthracene9-Carboxylate), DIDS (4,4'-diisothiocyanatostilbene-2,2' -disulfonic acid), ATP, and L-(+)-Lactic acid were obtained from Sigma Chemicals (St Louis, MO). The inhibitor of outwardly rectifying chloride channels TS-TM calix[4]arene $(5,11,17,23$-tetrasulfonato-25,26,27,28-tetramethoxy-calix[4]arene) was generously given by Drs. Singh and Bridges (University of Pittsburgh, Pittsburgh, USA). For experiments using chloride transport inhibitors, DPC, DIDS, glibenclamide, 9-AC, were dissolved in dimethylsulfoxide $\mathrm{Me}_{2} \mathrm{SO}$ (final concentration $0.1 \%$ ). In 
control experiments, the currents or efflux were not altered by $\mathrm{Me}_{2} \mathrm{SO}$.

\subsection{Statistics}

The results are expressed as means \pm SEM and $n$ refers to the number of independent experiments. Mean statistical analysis was performed on raw data. In order to compare sets of data, we used either analysis of variance (ANOVA) or the student $t$-test. Differences were considered statistically significant when $P<0.05$, ns: non significant difference, $* P<0.05$, $* * P<0.01$, *** $P<0.001$. All statistical tests were performed using the GraphPad Prism version 3.0 for Windows (GraphPad Software, San Diego, California, USA).

\section{RESULTS}

\subsection{Activation of a chloride current by various extracellular acids in rat Sertoli cells}

Figure 1 illustrates whole-cell recordings resulting from the stimulation of cultured rat Sertoli cells bathed in an extracellular medium maintained at $\mathrm{pH} 5$ either by $\mathrm{HCl}$ (Figs. 1A and 1B) or lactic acid (Figs. 1C and 1D). In control experiments (i.e. in an extracellular solution at $\mathrm{pH}$ 7.4), we recorded a very small basal current (Figs. 1A and 1C, top traces). Pronounced outwardly rectifying currents were consistently activated in Sertoli cells $(n=21)$ following the perfusion of an extracellular solution maintained at $\mathrm{pH} 5$ by $\mathrm{HCl}$ (Fig. 1A, bottom traces). Similar ionic currents were recorded in further cells $(n=9)$ after the perfusion of an extracellular solution maintained at $\mathrm{pH} 5$ by lactic acid (Fig. 1C, bottom traces). In both experimental situations, the acid-induced currents were activated instantaneously by depolarising pulses followed by a further slow activation. Because the average predicted reversal potential of the current is $-14 \pm 1.3 \mathrm{mV}$
( $n=30)$, a value near the equilibrium potential for $\mathrm{Cl}^{-}\left(\mathrm{E}_{\mathrm{Cl}^{-}}=-25 \mathrm{mV}\right)$, we concluded that $\mathrm{Cl}^{-}$is the main ion carrying the current. Moreover, the calculated relative permeability between chloride and sodium $\left(\mathrm{P}_{\mathrm{Cl}}: \mathrm{P}_{\mathrm{Na}}\right)$ fitted by the GHK equation is $6.05 \pm 1.07(n=9)$ indicating that $\mathrm{Cl}^{-}$ is 6 -fold more permeable than $\mathrm{Na}^{+}$. Therefore, this current will be hereafter denoted $\mathrm{ICl}_{\text {acid. }}$.

For each experimental condition, we expressed the amplitude of the current as the density of current (in $\mathrm{pA} / \mathrm{pF}$ ). Steady-state current-density curves of $\mathrm{HCl}$ or lactic acid-induced $\mathrm{ICl}_{\text {acid }}$ generated by our pulse protocol revealed a strong outward rectification (Figs. 1B and 1D). For example, the basal current density measured at $+60 \mathrm{mV}$ from 30 cells was $1.4 \pm 0.15 \mathrm{pA} / \mathrm{pF}$. The averaged current densities for $\mathrm{ICl}_{\text {acid }}$ measured at $+60 \mathrm{mV}$ were $67.45 \pm 9.95$ $\mathrm{pA} / \mathrm{pF}(n=21)$ and $69.65 \pm 9.22 \mathrm{pA} / \mathrm{pF}$ $(n=9)$ with $\mathrm{HCl}$ and lactic acid, respectively. These values were significantly different from the basal value $(P<0.001)$. However, the amplitudes of $\mathrm{ICl}_{\text {acid }}$ stimulated either by $\mathrm{HCl}$ or lactic acid were not significantly different. There were also no significant differences between the calculated mean conductances for inward and outward currents $\left(G_{\text {in }}\right.$ at $-60 \mathrm{mV}$ and $G_{\text {out }}$, at $+60 \mathrm{mV}$ respectively) for cells stimulated by either $\mathrm{HCl}\left(\mathrm{G}_{\mathrm{in}}=1.1 \pm 0.2 \mathrm{nS}\right.$; $\mathrm{G}_{\text {out }}=35.5 \pm 2 \mathrm{nS} ; n=9$ ) or lactic acid $\left(\mathrm{G}_{\text {in }}=1.2 \pm 0.3 \mathrm{nS} ; \mathrm{G}_{\text {out }}=36 \pm 4 \mathrm{nS}\right.$; $n=9)$.

In a second set of experiments, we performed iodide $\left({ }^{125} \mathrm{I}\right)$ efflux to further study and compare the $\mathrm{Cl}^{-}$transports after stimulating rat Sertoli cells by various extracellular acids. In control experiments, i.e. basal condition at $\mathrm{pH} 7.4,{ }^{125} \mathrm{I}$ efflux relative rate $(r)$ was $0.066 \pm 0.007 \mathrm{~min}^{-1}$ $(n=20)$. A significant efflux was observed (Fig. 1E) with cells incubated in an acid solution maintained at $\mathrm{pH} 5$ either with $\mathrm{HCl}$ $(n=25)$, lactic acid $(n=20)$ or aspartic acid $(n=4)$. It can be seen from the 

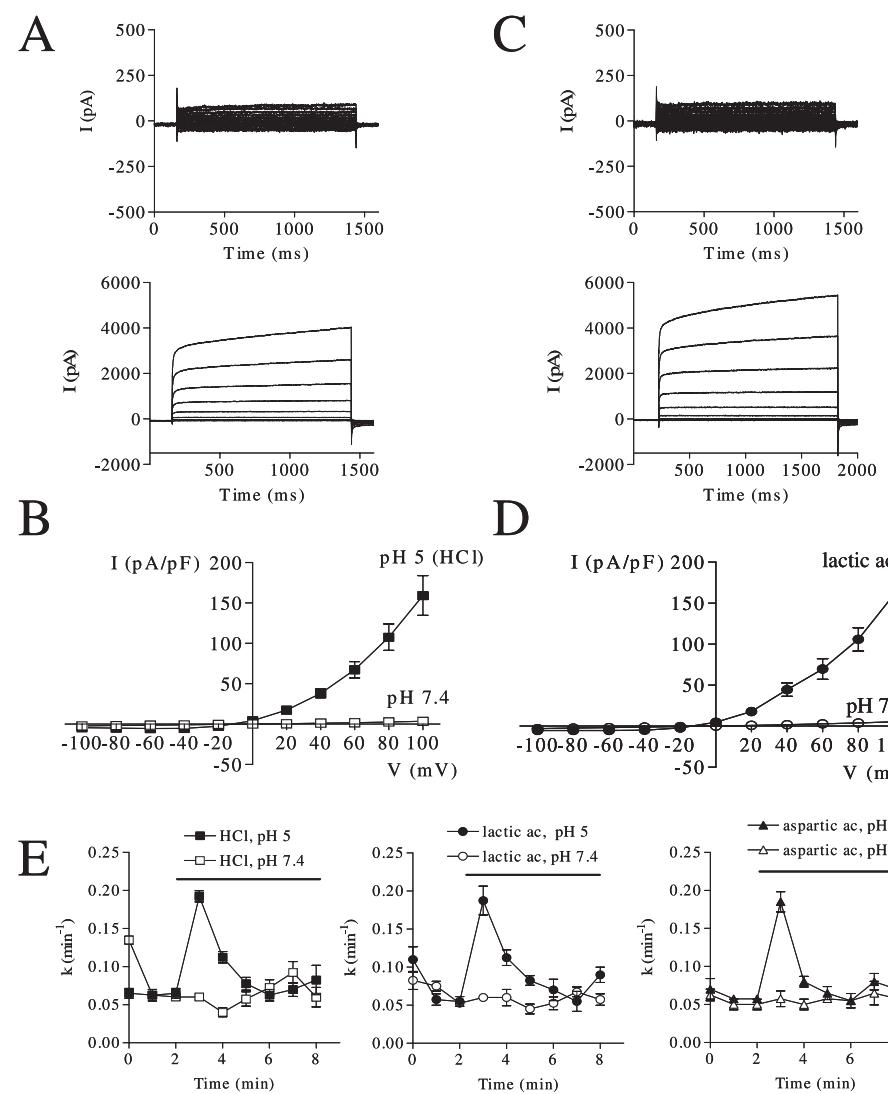

$\mathrm{D}$

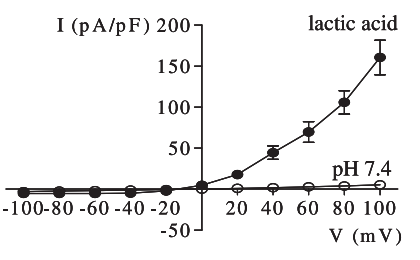

$\mathrm{F}$

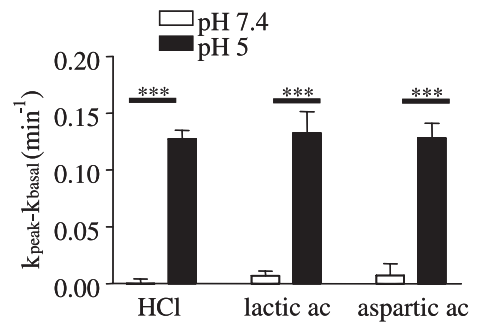

Figure 1. External acidification activates $\mathrm{Cl}^{-}$channels in Sertoli cells. (A) Whole cell patch clamp recordings performed on rat Sertoli cells bathed with a NaCl-rich solution at $\mathrm{pH} 7.4$ (up) and $\mathrm{pH} 5$ (down). (B) The corresponding current density/voltage relationship is given for each condition ( $n=$ 21). Data are presented as mean \pm SEM. (C) Whole cell patch clamp recordings performed on rat Sertoli cells bathed with control solution at $\mathrm{pH} 7.4$ (up) and with $9 \mathrm{mM}$ lactic acid (down) to maintain a $\mathrm{pH}$ 5. (D) The corresponding current density/voltage relationship is given for these conditions $(n=9)$. (E) Time-dependent iodide efflux performed on rat Sertoli cells bathed with a $\mathrm{NaCl}$-rich solution at pH 5 with $\mathrm{HCl}(n=25)$, with $9 \mathrm{mM}$ lactic acid $(n=20)$ and with $6 \mathrm{mM}$ aspartic acid $(n=4)$. $\mathrm{pH} 7.4$ corresponds to the basal condition $(n=20)$. k: rate of iodide efflux. (F) Bar graphs presenting the effects of $\mathrm{HCl}$, lactic acid and aspartic acid on iodide efflux in Sertoli cells. All results are means \pm SEM. ns, no significant difference; $* * * P<0.001$. 
time-dependent representation of the efflux rate (Fig. 1E) that the stimulation was almost immediate within the first minute after adding the acid (corresponding to $t=$ $3 \mathrm{~min}$ ). The rate constants were maximum after $1 \mathrm{~min}$ and then decreased and returned to the basal value because more than $80 \%$ of the radiotracer had left the cell through the opening of acid-activated $\mathrm{Cl}^{-}$channels. The stimulation either with $\mathrm{HCl}$, lactic acid or aspartic acid reached a comparable maximum level (Fig. 1F). The corresponding relative rates were $0.127 \pm$ $0.007 \mathrm{~min}^{-1}(n=25)$ for $\mathrm{HCl}, 0.132 \pm$ $0.018 \mathrm{~min}^{-1}(n=20)$ for lactic acid and $0.128 \pm 0.013 \mathrm{~min}^{-1}(n=4)$ for aspartic acid (black bars, Fig. 1F). By contrast, when the solutions containing $\mathrm{HCl}$ or lactic acid were buffered at $\mathrm{pH} 7.4$, no stimulation could be detected. In this experimental condition, the calculated relative rates were $0.06 \pm 0.004 \min ^{-1}(n=25)$ for $\mathrm{HCl}, 0.07 \pm 0.004 \mathrm{~min}^{-1}(n=20)$ for lactic acid and $0.075 \pm 0.01 \mathrm{~min}^{-1}(n=4)$ for aspartic acid (open bars, Fig. 1F, $P<$ 0.001 ). Therefore these experiments and the whole-cell recordings presented above collectively demonstrate the existence of specific acid-activated $\mathrm{Cl}^{-}$channels in cultured rat Sertoli cells.

\subsection{Inhibition by glibenclamide, DIDS, DPC but not by TS-TM calix[4]arene nor 9-AC}

One of the properties that distinguish $\mathrm{Cl}^{-}$channels is the sensitivity to a panel of inhibitors. Several inhibitors were then used to decipher a pharmacological hallmark of the $\mathrm{ICl}_{\text {acid }}$. In the absence of a specific inhibitor of $\mathrm{Cl}^{-}$channels, we decided to use a range of chemically unrelated derivatives. The cells were stimulated at $\mathrm{pH} 5$ and $\mathrm{Cl}^{-}$channel inhibitors were added in the bath solution containing $2 \mathrm{mM}$ extracellular $\mathrm{Ca}^{2+}$.

Sulfonylurea glibenclamide, besides its well known property of inhibition of the sulfonylurea receptor, has been shown to inhibit, at high concentration, $\mathrm{Cl}^{-}$channels including the CFTR $\mathrm{Cl}^{-}$channel [24-26]. Whole-cell patch-clamp recordings demonstrate the inhibition of $\mathrm{ICl}_{\text {acid }}$ (Fig. 2A) by $100 \mu \mathrm{M}$ glibenclamide (Fig. 2B). The current amplitude measured at $+60 \mathrm{mV}$ in 4 Sertoli cells bathed in a solution at $\mathrm{pH} 5$ was $3640 \pm$ 213.7 pA (Fig. 2C) and decreased to $1598 \pm 197.4 \mathrm{pA}(n=4$, Fig. $2 \mathrm{C})$ in the presence of $100 \mu \mathrm{M}$ glibenclamide. Previous work [18] has shown no- $\mathrm{Ca}^{2+}$ dependent activation of $\mathrm{ICl}_{\text {acid }}$. Here, we tested the $\mathrm{Ca}^{2+}$ effect on $\mathrm{ICl}_{\text {acid }}$ inhibition. The concentration-dependent inhibition of the iodide efflux (Fig. 2D) indicates an $\mathrm{IC}_{50}=$ $31 \pm 1.2 \mu \mathrm{M}(n=4)$ with $2 \mathrm{mM}$ extracellular $\mathrm{Ca}^{2+}$ and an $\mathrm{IC}_{50}=39 \pm 1.4 \mu \mathrm{M}$ in free-extracellular $\mathrm{Ca}^{2+}(n=4)$. Because these two values are not significantly different, we conclude that $\mathrm{ICl}_{\text {acid }}$ is inhibited by glibenclamide in a $\mathrm{Ca}^{2+}$-independent manner. Surprisingly, the effects of glibenclamide appeared different when measured using whole-cell recording or alternatively radiotracers $(50 \%$ block with $0.1 \mathrm{mM}$ using patch-clamp and $80 \%$ inhibition using iodide efflux). This discrepancy was due to the methods: (i) the cells were incubated with glibenclamide during $30 \mathrm{~min}$ before activation by $\mathrm{pH} 5$ with the iodide efflux technique while in the patch-clamp technique the inhibitor was added following this activation, (ii) the cell number tested with these two techniques was different (one cell using a whole-cell vs. a cell population using an iodide efflux).

The two classical inhibitors DIDS and DPC were then tested (Fig. 3). Concentration-response relationships were constructed from separate experiments using increasing concentrations of inhibitors from $3 \mu \mathrm{M}$ to $300 \mu \mathrm{M}$ ( $n=4$ for each concentration). Half-maximal effective concentrations for inhibition $\left(\mathrm{IC}_{50}\right)$ of the acid-activated $\mathrm{Cl}^{-}$transport were $27 \pm$ $1 \mu \mathrm{M}$ for DIDS and $86 \pm 5 \mu \mathrm{M}$ for DPC 
A

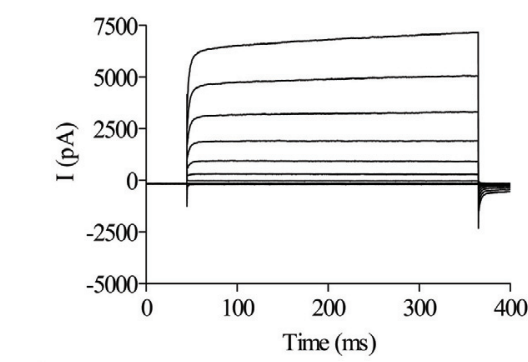

$\mathrm{C}$

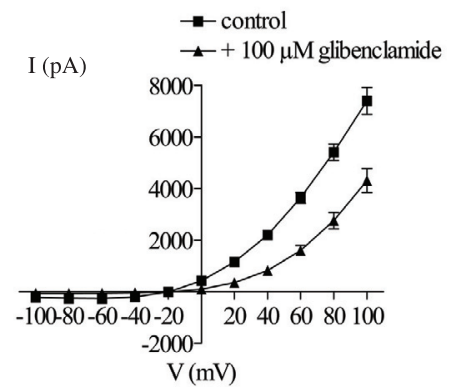

$\mathrm{B}$

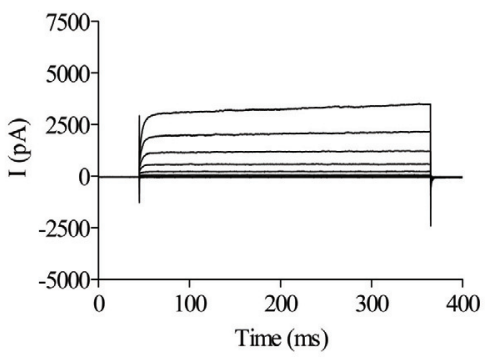

$\mathrm{D}$

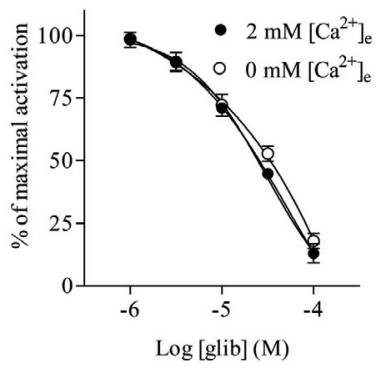

Figure 2. Effect of glibenclamide on $\mathrm{ICl}_{\text {acid. }}$ ( $\mathbf{A}$ and $\mathbf{B}$ ) Whole cell patch clamp recordings performed on a rat Sertoli cell bathed with a NaCl-rich solution at $\mathrm{pH} 5$ without (A) or with $100 \mu \mathrm{M}$ glibenclamide (B). (C) The corresponding current/voltage relationship is given for each condition $(n=4)$. (D) Concentration-response relationships between the concentration of glibenclamide and the percentage of maximal activation of the iodide efflux in Sertoli cells in the presence or absence of extracellular calcium. All results are means \pm SEM of 4 experiments for each protocol.

(Figs. 3A and 3B). We observed an inhibition $>80 \%$ by $500 \mu \mathrm{M}$ of the disulfonic stilbene DIDS and $>77 \%$ by $500 \mu \mathrm{M}$ of the arylaminobenzoate DPC in the presence or absence of extracellular calcium ( $n=4$, Fig 3C). However, in the presence of $1 \mathrm{mM}$ Anthracene-9-Carboxylate (9-AC) an inhibitor of ClC-1 [27] and other $\mathrm{Cl}^{-}$channels [25], no inhibition was found ( $n=4$, Fig. $3 C$ ). The sulfonated calixarene TS-TM calix[4]arene $(5,11,17,23$-tetrasulfonato-25,26,27,28-tetramethoxy-calix[4]arene) [28] is a highly potent inhibitor of outwardly rectifying $\mathrm{Cl}^{-}$channels (so called ORCC). Figure 3C shows that $100 \mathrm{nM}$ TS-TM calix[4]arene did not block the iodide efflux activated by $\mathrm{HCl}$ in the presence of extracellular calcium. Thus the $\mathrm{Cl}^{-}$channel inhibitors DIDS, DPC and glibenclamide inhibit $\mathrm{ICl}_{\text {acid }}$, independently of the presence of extracellular calcium. The profile for inhibition of $\mathrm{ICl}_{\text {acid }}$ was therefore DIDS $\approx$ glibenclamide $>$ DPC $\gg$ TS-TM calix[4]arene, 9-AC. The same inhibitory profile was obtained when $\mathrm{ICl}_{\text {acid }}$ was stimulated by lactic acid (Fig. 3D).

\subsection{Pharmacological comparison of $\mathrm{Cl}^{-}$ transports regulated by acid, cell volume and ATP}

A global analysis of the $\mathrm{Cl}^{-}$channels in Sertoli cells using iodide efflux techniques 
A

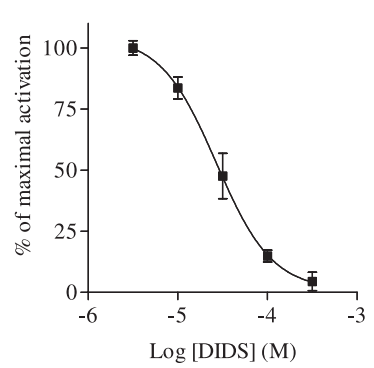

B

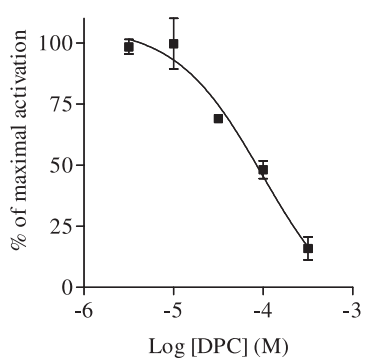

$\mathrm{C}$

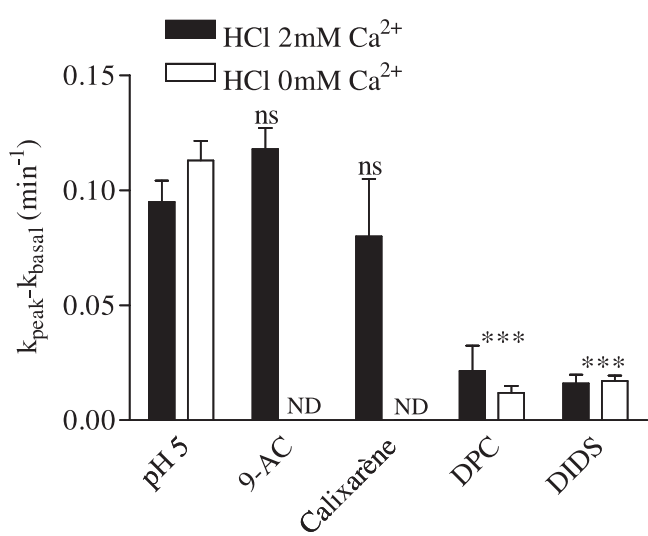

$\mathrm{D}$

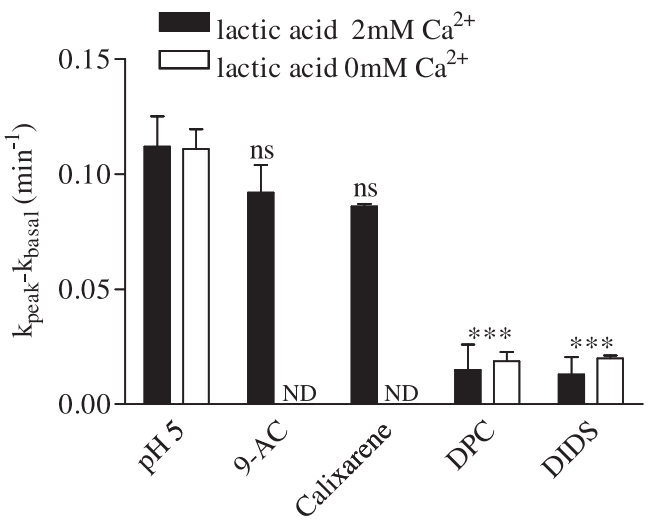

Figure 3. Effect of DIDS, DPC, 9-AC and calixarene on the iodide efflux. (A and B) Concentrationresponse relationships for DIDS (A) and DPC (B). The data are expressed as a percentage of maximal activation of the iodide efflux in Sertoli cells in the presence of different concentrations of the inhibitor. (C) Histograms presenting the effect of $1 \mathrm{mM} 9-\mathrm{AC}, 500 \mu \mathrm{M}$ DPC, $500 \mu \mathrm{M}$ DIDS and $100 \mathrm{nM}$ calixarene on $\mathrm{HCl}$ activation in the presence or absence of extracellular calcium. (D) Histograms presenting the inhibitory profile of the $\mathrm{pH}$-induced chloride current stimulated by lactic acid in the presence or absence of calcium. All results are means \pm SEM of 4 experiments for each protocol. $n s$, no significant difference; $* * * P<0.001 ; \mathrm{ND}$, not determined. 
and whole cell patch-clamp has revealed the presence of several other $\mathrm{Cl}^{-}$conductances [18]. A molecular and whole cell patch clamp analysis of rat Sertoli cells already identified the following voltagedependent $\mathrm{Cl}^{-}$channels: $\mathrm{rClC}-2, \mathrm{rClC}-3$, rClC-6, $\mathrm{rClC}-7$ and a volume-activated $\mathrm{Cl}^{-}$ current (referred as $\mathrm{ICl}_{\text {swell }}$ ) [18]. $\mathrm{ICl}_{\text {swell }}$ is activated following a hypo-osmotic challenge with a voltage-dependent activation at depolarizing pulses followed by a pronounced inactivation [18]. In addition, because the nucleotide ATP induces an increase of the intracellular calcium concentration $\left[\mathrm{Ca}^{2+}\right]_{\mathrm{i}}[16,29]$, we investigated the effect of $100 \mu \mathrm{M}$ ATP on the $\mathrm{Cl}^{-}$currents in Sertoli cells.

Iodide efflux experiments were performed to compare $\mathrm{Cl}^{-}$transports activated by ATP or hypo-osmotic challenge. Figure 4 shows that the two experimental conditions, i.e. a hypo-osmotic challenge or addition of $100 \mu \mathrm{M}$ ATP in the extracellular bath induced two different responses in Sertoli cells. With cells exposed to a hypo-osmotic solution, the iodide efflux was stimulated within the first minute but with a maximal response two minutes after the addition of the hypo-osmotic solution with a relative rate of $0.180 \pm$ $0.037 \mathrm{~min}^{-1}$ ( $n=6$, Fig. 4A). This response was not inhibited by 9 -AC, the relative rate was $0.167 \pm 0.055 \mathrm{~min}^{-1}(n=$ 8, Fig. 4A). With cells exposed to $100 \mu \mathrm{M}$ ATP in the extracellular bath, the iodide efflux was stimulated with a relative rate of $0.121+0.025 \mathrm{~min}^{-1}$ after one minute (faster than with the hypo-osmotic solution) followed by a rapid decline of the iodide efflux ( $n=12$, Fig. 4C), respectively. The control relative rate calculated in the absence of stimulation was $0.014 \pm$ $0.002 \min ^{-1}(n=22)$. The differences between the two experimental conditions with respect to the control was found to be statistically significant $(P<0.001) .9$-AC produced a significant inhibition of the relative rate $\left(0.052 \pm 0.002 \mathrm{~min}^{-1}, P<0.01\right.$; $n=8$, Fig. 4C). We then compared the effect of glibenclamide $(100 \mu \mathrm{M})$, DPC $(500 \mu \mathrm{M})$ and 9 -AC $(1 \mathrm{mM})$ on the ATPand hypo-osmotic-activated iodide efflux. Glibenclamide neither inhibits the hypoosmotic-activated iodide efflux $(n=10$, Fig. 4B) nor the ATP-activated iodide efflux ( $n=14$, Fig. 4D). Whereas $500 \mu \mathrm{M}$ DPC (Fig. 4B and D) and $500 \mu \mathrm{M}$ DIDS (not shown) inhibited both effluxes, the compound 9-AC only inhibited the ATPactivated iodide efflux (Fig. 4D) but not the hypo-osmotic-activated iodide efflux (Fig. 4B) ( $n=8$ for each experimental condition). Figure $4 \mathrm{E}$ shows a typical whole-cell experiment identifying outwardly rectifying $\mathrm{Cl}^{-}$currents stimulated by $100 \mu \mathrm{M}$ ATP added to the bath perfusion and presenting a slow activation at positive potentials. This current denoted $\mathrm{ICl}_{\text {ATP }}$ is fully blocked by $500 \mu \mathrm{M}$ DPC (Fig. 4F). By contrast, with a bath perfusion containing the adenylate cyclase activator forskolin $(10 \mu \mathrm{M})$ used to increase the cell cAMP level, no further $\mathrm{Cl}^{-}$currents could be stimulated (not shown). We determined that the inhibition profile was $\mathrm{DIDS} \approx \mathrm{DPC}=9-\mathrm{AC}>>$ glibenclamide for the ATP-activated $\mathrm{Cl}^{-}$transport and DIDS $\approx$ DPC $\gg$ glibenclamide, 9-AC for the hypo-osmotic response.

\section{DISCUSSION}

The present study was designed to characterize the pharmacological properties of the acid-activated $\mathrm{Cl}^{-}$current, $\mathrm{ICl}_{\text {acid }}$, recently identified in cultured rat Sertoli cells and to compare its pharmacological signature to that of two other endogenous $\mathrm{Cl}^{-}$channels activated by extracellular ATP $\left(\mathrm{ICl}_{\mathrm{ATP}}\right)$ and hypo-osmotic solution $\left(\mathrm{ICl}_{\text {swell }}\right)$. The principal findings of this study were (i) $\mathrm{ICl}_{\text {acid }}$ can be stimulated by various acid species $(\mathrm{HCl}$, aspartic acid and the physiologically relevant lactic acid) suggesting that the most 


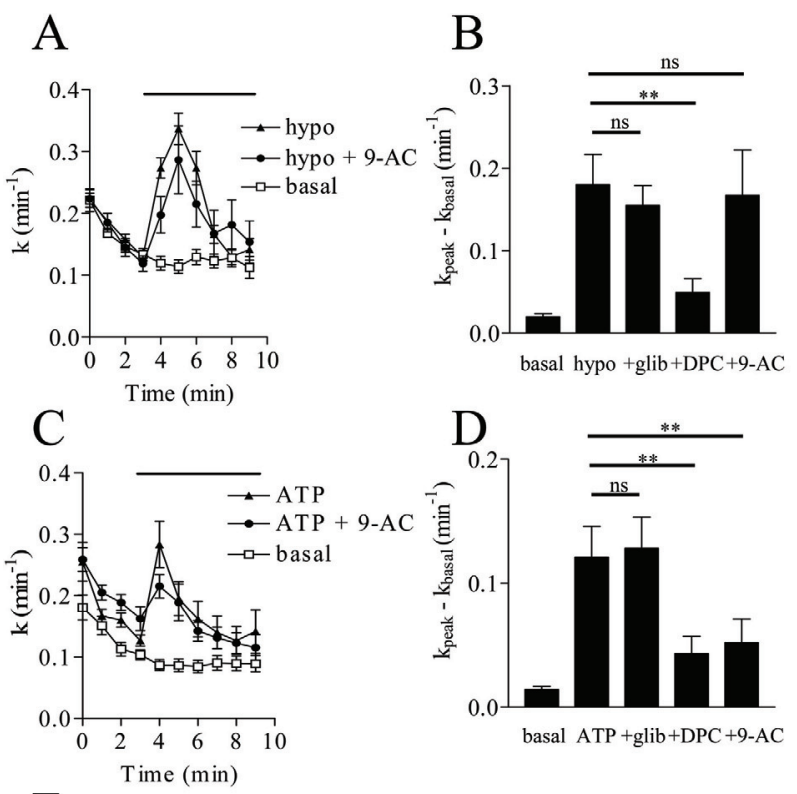

$\mathrm{E}$

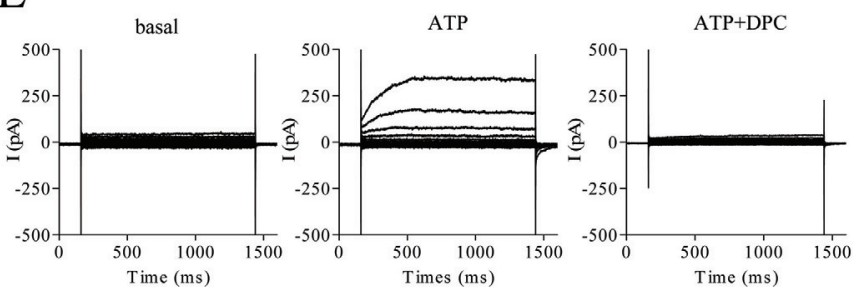

$\mathrm{F}$

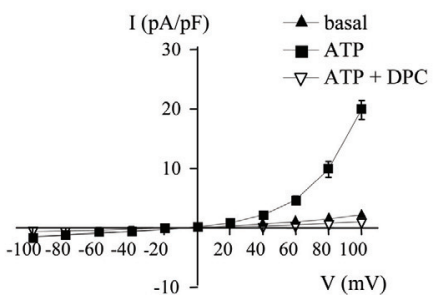

Figure 4. Stimulation of $\mathrm{Cl}^{-}$channels by $100 \mu \mathrm{M}$ ATP and hypo-osmotic challenge. (A) Iodide efflux performed on rat Sertoli cells bathed with a hypo-osmotic challenge $(n=6)$ and in the presence of $1 \mathrm{mM}$ 9-AC $(n=8)$. (B) Bar graphs presenting the effects of $100 \mu \mathrm{M}$ glibenclamide, $500 \mu \mathrm{M}$ DPC and $1 \mathrm{mM}$ 9-AC on the hypo-osmotic-stimulated efflux. (C) Iodide efflux from rat Sertoli cells bathed with $100 \mu \mathrm{M}$ ATP $(n=12)$ and in the presence of $1 \mathrm{mM} 9-\mathrm{AC}(n=8)$. (D) Bar graphs presenting the effects of $100 \mu \mathrm{M}$ glibenclamide, $500 \mu \mathrm{M}$ DPC and $1 \mathrm{mM}$ 9-AC on the ATP-mediated efflux. (E) Whole cell patch clamp recordings performed on a rat Sertoli cell without (noted basal) or with $100 \mu \mathrm{M}$ ATP in the bath medium. The full inhibition of the outwardly rectifying $\mathrm{Cl}^{-}$current by $500 \mu \mathrm{M}$ DPC is illustrated on the right traces. (F) The corresponding current density/voltage relationship is given for each condition $(n=4)$. Data are presented as mean \pm SEM. $n s$, no significant difference; $* * P<0.01$. 
important determinant is the concentration of protons itself rather than the nature of the acid; (ii) the profile for inhibition of $\mathrm{ICl}_{\text {acid }}$ was DIDS $\approx$ glibenclamide $>$ DPC $\gg$ TS-TM calix[4]arene, 9-AC; (iii) an ATP-activated $\mathrm{Cl}^{-}$channel $\mathrm{ICl}_{\mathrm{ATP}}$ was inhibited by DIDS $\approx \mathrm{DPC} \approx$ 9-AC $\gg$ glibenclamide; (iv) a swellingactivated $\mathrm{Cl}^{-}$channel $\mathrm{ICl}_{\text {swell }}$ was inhibited by DIDS $\approx$ DPC $>>$ 9-AC, glibenclamide. Thus glibenclamide appears to be a relatively good discriminator of $\mathrm{ICl}_{\text {acid }}$ compared to $\mathrm{ICl}_{\mathrm{ATP}}$ or $\mathrm{ICl}_{\text {swell }}$ whereas $9-\mathrm{AC}$ is a good discriminator of $\mathrm{ICl}_{\mathrm{ATP}}$ compared to $\mathrm{ICl}_{\text {acid }}$ or $\mathrm{ICl}_{\text {swell }}$.

Several members of the voltagedependent $\mathrm{ClC}$ family of $\mathrm{Cl}^{-}$channels are activated, inhibited or gated by $\mathrm{pH}[27,30]$. In rat Sertoli cells, electrophysiological and molecular analysis have revealed the expression of several types of $\mathrm{Cl}^{-}$ channels among them $\mathrm{Ca}^{2+}$-dependent [16], swelling-activated [18] and four voltage-dependent $\mathrm{Cl}^{-}$channels, i.e. ClC-2, ClC-3, ClC-6 and ClC-7 [18]. We have already ruled out the possibility that any of these members could contribute to $\mathrm{ICl}_{\text {acid }}$ [18]. To our knowledge, there are only few examples of native $\mathrm{Cl}^{-}$channels activated by external protons. The best studied $\mathrm{pH}$-sensitive $\mathrm{Cl}^{-}$current is the inwardly rectifying $\mathrm{Cl}^{-}$channel $\mathrm{ClC}-2$ for which numerous studies on both native and cloned channels indicated an extreme sensitivity to extracellular protons and an inhibition by $\mathrm{Cd}^{2+}$ [30-34]. A recent study characterized an endogenous $\mathrm{Cl}^{-}$current in transformed human embryonic kidney HEK-293 cells, activated by extracellular $\mathrm{pH}$ [35]. The corresponding current shares some characteristics with the $\mathrm{ICl}_{\text {acid }}$ found in Sertoli cells, i.e an outward rectification with a slow voltage-dependent activation, a lack of dependence on intraor extracellular calcium, blocking by DIDS and DPC [18, 35]. However, we determined a different anionic selectivity i.e. $\mathrm{Cl}^{-}>\mathrm{Br}^{-}>\mathrm{I}^{-}>$gluconate [18], whereas in HEK-293 the current has the following selectivity $\mathrm{I}^{-}>\mathrm{Br}^{-}>\mathrm{Cl}^{-}>$gluconate [35]. Moreover in their conclusions, these authors suggested that $\mathrm{ICl}_{\text {acid }}$ and $\mathrm{ICl}_{\text {swell }}$ could represent two different transition states of the same channel suggesting that the extracellular acidification could reflect a novel stimulus for activating $\mathrm{ICl}_{\text {swell }}$ resulting in an alteration of its biophysical properties [35]. In Sertoli cells, this hypothesis is unlikely, both $\mathrm{ICl}_{\mathrm{acid}}$ and $\mathrm{ICl}_{\text {swell }}$ co-exist but we clearly determined different biophysical properties (slow voltage-dependent activation for $\mathrm{ICl}_{\text {acid }}$, fast voltage-dependent activation, and time-dependent inactivation for $\mathrm{ICl}_{\text {swell }}$ ) as well as different pharmacological properties (glibenclamide-sensitivity for $\mathrm{ICl}_{\mathrm{acid}}$, glibenclamide-insensitivity for $\mathrm{ICl}_{\text {swell }}$ ) (this study). Lambert and Oberwinkler [36] identified the proton-activated, outwardly rectifying currents expressed in HEK293 cells. They also described distinct and separable properties from those of the volume regulated anion currents, even under identical experimental conditions. These authors concluded the proton-activated anion currents and the volume-regulated anion currents are linked to physically distinct populations of ion channels. To clarify if $\mathrm{ICl}_{\text {acid }}$ and $\mathrm{ICl}_{\text {swell }}$ are provided by two different channels, it is necessary to identify the molecular properties of the proteins responsible for these two conductances.

Previous works have shown that an acidic $\mathrm{pH}$ is required for the maturation process of sperm cells $[37,38]$ and that the secretion of a large amount of lactate by Sertoli cells could be responsible for the establishment of the acid environment $[39,40]$. In the present study, we characterized in rat Sertoli cells some elements of the pharmacology and regulation of novel outwardly rectifying $\mathrm{Cl}^{-}$channels, $\mathrm{ICl}_{\text {acid }}$, activated by extracellular acid, including lactic acid. We have previously described the $\mathrm{pH}$-dependence of this current 
and we estimated the half-maximal stimulation around $\mathrm{pH} 5.5$ [18]. Although it is premature to conclude that $\mathrm{ICl}_{\text {acid }}$ plays a role in the physiology of Sertoli cells regarding the regulation of lactic acid, it nevertheless represents a good potential candidate. Moreover, another interesting issue is that $\mathrm{ICl}_{\text {acid }}$ is noticeable only at positive voltages. Further studies will be necessary to clear this point.

Finally, the hormonal regulation of the secretion of a $\mathrm{Cl}^{-}$and $\mathrm{K}^{+}$-rich fluid by Sertoli cells is important in spermatogenesis. It involves multiple signaling pathways, including regulation of adenyl cyclase with increasing or decreasing cAMP levels, calcium homeostasis and purinergic receptor stimulation [41]. Many endogenous ion channels have been described in Sertoli cells [41] but sparse information concerning their role in the physiology of Sertoli cells and spermatogenesis are available. The identification and pharmacological characteristics of the three types of $\mathrm{Cl}^{-}$channels identified in our rat Sertoli cell model may help to promote our understanding of the biophysical characteristics and physiological roles of ion channels in the Sertoli cell, a cell at the blood-testis barrier.

\section{ACKNOWLEDGEMENTS}

This work was supported by the Conseil Régional du Poitou-Charentes, CNRS and CFPronet. Céline Auzanneau is supported by a studentship form Région Poitou-Charente and Caroline Norez is supported by a studentship from Vaincre La Mucoviscidose.

\section{REFERENCES}

[1] Carreau S, Foucault P, Drosdowsky MA. Sertoli cells. Functional aspects compared in rats, pigs and man. Ann Endocrinol (Paris) 1994, 55: 203-220 (in French).
[2] Lui WY, Mruk D, Lee WM, Cheng CY. Sertoli cell tight junction dynamics: their regulation during spermatogenesis. Biol Reprod 2003, 68: 1087-1097.

[3] Russel L, Ettlin R, Hikim A, Clegg E. The Sertoli cell. In: Histological and histopathological evaluation of the testis. Clearwater: Cache River Press, 1990, p 29-36.

[4] Schlatt S, Meinhardt A, Nieschlag E. Paracrine regulation of cellular interactions in the testis: factors in search of a function. Eur J Endocrinol 1997, 137: 107-117.

[5] Meehan T, Schlatt S, O'Bryan MK, de Kretser DM, Loveland KL. Regulation of germ cell and Sertoli cell development by activin, follistatin, and FSH. Dev Biol 2000, 220: 225-237.

[6] Orth JM. Proliferation of Sertoli cells in fetal and postnatal rats: a quantitative autoradiographic study. Anat Rec 1982, 203: 485492 .

[7] Sasaki M, Yamamoto M, Arishima K, Eguchi Y. Effect of follicle-stimulating hormone on Sertoli cell division in cultures of fetal rat testes. Biol Neonate 2000, 78: 48-52.

[8] Clermont Y. Introduction to the Sertoli Cell. In: MD RLaG (Ed), The Sertoli Cell, USA: Cache River Press, 1993, p 21-25.

[9] Gorczynska E, Handelsman DJ. The role of calcium in follicle-stimulating hormone signal transduction in Sertoli cells. J Biol Chem 1991, 266: 23739-23744.

[10] Gorczynska-Fjalling E. The role of calcium in signal transduction processes in Sertoli cells. Reprod Biol 2004, 4: 219-241.

[11] Conlin PR, Cirillo M, Zerbini G, Williams GH, Canessa ML. Calcium-mediated intracellular acidification and activation of $\mathrm{Na}(+)-\mathrm{H}+$ exchange in adrenal glomerulosa cells stimulated with potassium. Endocrinology 1993, 132: 1345-1352.

[12] McLeskey SB, Dowds C, Carballada R, White RR, Saling PM. Molecules involved in mammalian sperm-egg interaction. Int Rev Cytol 1998, 177: 57-113.

[13] Jutte NH, Jansen R, Grootegoed JA, Rommerts FF, Clausen OP, van der Molen HJ. Regulation of survival of rat pachytene spermatocytes by lactate supply from Sertoli cells. J Reprod Fertil 1982, 65: 431-438. 
[14] Jutte NH, Grootegoed JA, Rommerts FF, van der Molen HJ. Exogenous lactate is essential for metabolic activities in isolated rat spermatocytes and spermatids. J Reprod Fertil 1981, 62: 399-405.

[15] Taranta A, Morena AR, Barbacci E, D’Agostino A. Omega-Conotoxin-sensitive $\mathrm{Ca}^{2+}$ voltage-gated channels modulate protein secretion in cultured rat Sertoli cells. Mol Cell Endocrinol 1997, 126: 117-123.

[16] Lalevee N, Joffre M. Inhibition by cAMP of calcium-activated chloride currents in cultured Sertoli cells from immature testis. J Membr Biol 1999, 169: 167-174.

[17] Boockfor FR, Morris RA, DeSimone DC, Hunt DM, Walsh KB. Sertoli cell expression of the cystic fibrosis transmembrane conductance regulator. Am J Physiol 1998, 274: C922-930.

[18] Auzanneau C, Thoreau V, Kitzis A, Becq F. A Novel voltage-dependent chloride current activated by extracellular acidic $\mathrm{pH}$ in cultured rat Sertoli cells. J Biol Chem 2003, 278: 19230-19236.

[19] Hamill OP, Marty A, Neher E, Sakmann B, Sigworth FJ. Improved patch-clamp techniques for high-resolution current recording from cells and cell-free membrane patches. Pflugers Arch 1981, 391: 85-100.

[20] Marivingt-Mounir C, Norez C, Derand R, Bulteau-Pignoux L, Nguyen-Huy D, Viossat B, et al. Synthesis, SAR, crystal structure, and biological evaluation of benzoquinoliziniums as activators of wild-type and mutant cystic fibrosis transmembrane conductance regulator channels. J Med Chem 2004, 47: 962-972.

[21] Norez C, Heda GD, Jensen T, Kogan I, Hughes LK, Auzanneau C, et al. Determination of CFTR chloride channel activity and pharmacology using radiotracer flux methods. J Cyst Fibros 2004, 3 Suppl 2: 119-121.

[22] Venglarik CJ, Bridges RJ, Frizzell RA. A simple assay for agonist-regulated $\mathrm{Cl}$ and $\mathrm{K}$ conductances in salt-secreting epithelial cells. Am J Physiol 1990, 259: C358-364.

[23] Derand R, Bulteau-Pignoux L, Becq F. The cystic fibrosis mutation G551D alters the non-Michaelis-Menten behavior of the cystic fibrosis transmembrane conductance regulator (CFTR) channel and abolishes the in- hibitory Genistein binding site. J Biol Chem 2002, 277: 35999-36004.

[24] Welsh MJ, Anderson MP, Rich DP, Berger HA, Denning GM, Ostedgaard LS, et al. Cystic fibrosis transmembrane conductance regulator: a chloride channel with novel regulation. Neuron 1992, 8: 821-829.

[25] Schultz BD, Singh AK, Devor DC, Bridges RJ. Pharmacology of CFTR chloride channel activity. Physiol Rev 1999, 79 (Suppl): S109-S144.

[26] Sheppard DN, Welsh MJ. Effect of ATPsensitive $\mathrm{K}+$ channel regulators on cystic fibrosis transmembrane conductance regulator chloride currents. J Gen Physiol 1992, 100: 573-591.

[27] Jentsch TJ, Stein V, Weinreich F, Zdebik AA. Molecular structure and physiological function of chloride channels. Physiol Rev 2002, 82: 503-568.

[28] Singh AK, Venglarik CJ, Bridges RJ. Development of chloride channel modulators. Kidney Int 1995, 48: 985-993.

[29] Lalevee N, Pluciennik F, Joffre M. Voltagedependent calcium current with properties of T-type current in Sertoli cells from immature rat testis in primary cultures. Biol Reprod 1997, 56: 680-687.

[30] Arreola J, Begenisich T, Melvin JE. Conformation-dependent regulation of inward rectifier chloride channel gating by extracellular protons. J Physiol 2002, 541: 103-112.

[31] Chesnoy-Marchais D, Fritsch J. Activation of hyperpolarization and atypical osmosensitivity of a $\mathrm{Cl}^{-}$current in rat osteoblastic cells. J Membr Biol 1994, 140: 173-188.

[32] Jordt SE, Jentsch TJ. Molecular dissection of gating in the ClC-2 chloride channel. Embo J 1997, 16: 1582-1592.

[33] Fritsch J, Edelman A. Modulation of the hyperpolarization-activated $\mathrm{Cl}^{-}$current in human intestinal T84 epithelial cells by phosphorylation. J Physiol 1996, 490: 115128.

[34] Kajita H, Whitwell C, Brown PD. Properties of the inward-rectifying $\mathrm{Cl}^{-}$channel in rat choroid plexus: regulation by intracellular messengers and inhibition by divalent cations. Pflugers Arch 2000, 440: 933-940.

[35] Nobles M, Higgins CF, Sardini A. Extracellular acidification elicits a chloride 
current that shares characteristics with ICl(swell). Am J Physiol Cell Physiol 2004, 287: C1426-C1435.

[36] Lambert S, Oberwinkler J. Characterization of a proton-activated, outwardly rectifying anion channel. J Physiol 2005, 567: 191213.

[37] Breton S, Hammar K, Smith PJ, Brown D. Proton secretion in the male reproductive tract: involvement of $\mathrm{Cl}^{-}$-independent HCO3 transport. Am J Physiol 1998, 275: C1134C1142.

[38] Mauduit C, Hamamah S, Benahmed M. Stem cell factor/c-kit system in spermatogenesis. Hum Reprod Update 1999, 5: 535545 .
[39] Riera MF, Meroni SB, Schteingart HF, Pellizzari EH, Cigorraga SB. Regulation of lactate production and glucose transport as well as of glucose transporter 1 and lactate dehydrogenase A mRNA levels by basic fibroblast growth factor in rat Sertoli cells. J Endocrinol 2002, 173: 335-343.

[40] Robinson R, Fritz IB. Metabolism of glucose by Sertoli cells in culture. Biol Reprod 1981, 24: 1032-1041.

[41] Filippini A, Riccioli A, De Cesaris P, Paniccia R, Teti A, Stefanini M, et al. Activation of inositol phospholipid turnover and calcium signaling in rat Sertoli cells by P2-purinergic receptors: modulation of follicle stimulating hormone responses. Endocrinology 1994, 134: 1537-1545. 
